\title{
Performances of KUB Chickens Fed Diets with Different Nutrient Densities and BS4 Enzyme Supplementation
}

\author{
A. P. Sinurat*, T. Haryati, A. Herliatika, \& N. Pratiwi \\ Indonesian Research Institute for Animal Production \\ Jalan Veteran III, Banjarwaru, Ciawi Bogor 16720, Indonesia \\ *Corresponding author: arnoldps57@yahoo.com \\ (Received 22-04-2021; Revised 26-08-2021; Accepted 02-09-2021)
}

\begin{abstract}
An experiment was conducted to study the effect of dietary enzyme supplementation (E) on the performance of KUB chickens fed different nutrient densities (ND). Diets with three densities: $70.7 \mathrm{~g}$ crude protein/Mcal or high (H), $66.1 \mathrm{~g}$ crude protein/Mcal or medium (M), and $59.3 \mathrm{~g}$ crude protein/ Mcal or low (L), were formulated and supplemented with or without enzyme. Diets were given in four feeding programs, i.e., H-M-L, H-M-M, M-M-L, and M-L-L during the starter (1-28 d), grower (29-56 d), and finisher (57-84 d) periods, respectively. Each treatment was replicated five times. Bodyweight gain (BWG), feed intake, and FCR were measured each period. At the end of the trial, carcass yield and internal organs were measured. Results of the experiment (1-84 d period) showed that the feed intake was significantly affected by ND. Chickens fed the H-M-L diets have the highest feed intake, while the lowest was found in chickens fed M-M-L diets. A significant interaction was found in the FCR. The best FCR was found in chickens fed the H-M-M diets without enzymes, but the best FCR was found on the M-M-L diets with enzymes. Livability, carcass yield, abdominal fat, liver, proventriculus, and gizzard weights were not affected by the treatments. The jejunum sizes of chickens were significantly longer when fed the low-density diet than those fed the higher nutrient density diet. The ileum sizes of chickens were significantly shorter than chickens fed the diet without enzymes. The highest income over feed cost was achieved when chickens were fed the M-M-L diets supplemented with enzymes. It is concluded that the best performance of growing KUB chickens was obtained when fed M-M-L diets supplemented with BS4 enzymes (30 Units of saccharification/kg diet) and when fed H-M-M diets without enzyme supplementation.
\end{abstract}

Keywords: KUB chickens; growing performance; nutrient density; enzyme

\section{INTRODUCTION}

KUB chicken is a new breed chicken produced by a selection of local or kampung chickens. The chicken breed has been introduced to farmers in almost all provinces in Indonesia. Although the productive performances of the KUB chickens are not as superior as the improved breed chickens, the demand for this chicken is increasing due to the egg taste and the meat quality matches the preferential of the Indonesian majority. The chickens also have better productivity (eggs and meat) than the ordinary local chickens (Saragih et al., 2019).

Farmers practiced various programs in feeding KUB chickens at present. Based on research, Hidayat et al. (2017) suggested the optimum ME: protein ratio in the diet for KUB chickens for the growing period (0-10 weeks) was 15.85 , i.e., $2950 \mathrm{kcal} \mathrm{ME} / \mathrm{kg}$ and $18.5 \%$ crude protein. Increasing or decreasing the ME: protein ratios resulted in poorer feed conversion ratios. Some studies have been conducted to determine the nutrient requirement of KUB chickens by mixing the commercial broiler diets with corn and rice bran (Mayora et al., 2018; Sari et al., 2017; Irawan et al., 2018). These studies showed that the best performance of the KUB chickens was achieved by feeding a diet with $3089 \mathrm{kcal} \mathrm{ME}$ and $18.9 \%$ protein for the starter period (Mayora et al., 2018), 12.8\%-15.6\% for the growing period (Sari et al., 2017), and 8.4\%$14.1 \%$ for the finishing period (Irawan et al., 2018). On the other hand, the Indonesian Standard Bureau (BSN, 2013a; 2013b) has published two standards of feed for growing local chickens, i.e., starter diet for chickens age 0 to 4 weeks and grower diet for chickens age $>4$ to 20 weeks. Since KUB chickens grow faster than ordinary local chickens, the standard nutrient requirement recommended for local chickens may not be suitable for the KUB chickens. Therefore, it is necessary to identify the optimum nutrient requirement of the KUB chickens.

Based on the above information, there is a variation in the recommendation of the levels of nutrients requirement and feeding program for growing local chickens. The information on nutrients requirements is an essential key used in formulating diets to reach an optimum diet with a low cost. Formulating a high-density diet is usually considered a high-quality feed and produces 
better performance when fed to chickens (Lamot et al., 2019). Still, it will make the feed price expensive while formulating a diet with lower nutrients than the chickens required, which will eventually impair the performance of the chickens.

Enzyme supplementation in the feed may improve the quality of the low-density diet by increasing the availability of nutrients in the diet. A new enzyme named BS4 enzyme has been investigated in our laboratory. The enzyme consists of $\beta$-mannanase, cellulase, $\beta$-mannosidase, and $\alpha$ - galactosidase (Sinurat et al., 2014). Supplementation of the enzyme in the diet is expected to increase nutrients digestibility of the feed. This condition implies that lower nutrients levels could be provided at a lower price to achieve similar performances. Nutrients requirement for local chickens is available, but there is no standard nutrient requirement for the selected local chickens (KUB). Therefore, this study is expected to find an appropriate nutrient density required by KUB chickens to support their growth performances during starter, grower, and finisher periods, especially if the enzyme is supplemented in the diet.

\section{MATERIALS AND METHODS}

All procedures in this experiment regarding the use of live animals were done according to the approval of The Animal Welfare Committee at the Indonesian Agency for Agricutural Research and Development: Balitbangtan/Balitnak/A/06/2020.

\section{Animals and Management}

A total of 440 day-old unsexed- KUB chicks were obtained from the hatchery of Balai Penelitian Ternak - Ciawi. The chicks were distributed randomly into 40 pens with 11 birds/pen. Each pen measuring 300 x $150 \mathrm{~cm}$ was covered with rice hull as deep litter and equipped with a light bulb as a heater during the starter period (1-28 d), a feeder, and a drinker. The chicks were reared and fed dietary treatments for starter ( 1 to $28 \mathrm{~d}$ ), grower ( 29 to $56 \mathrm{~d}$ ), and finisher (57 to $84 \mathrm{~d}$ ) periods. The starter feed was in crumble form, while the grower and finisher feeds were made in pelleted form. The experimental chickens had free access to feed and drinking water at all times.

\section{Experimental Diets}

The experiment was divided into three stages of growth, i.e., starter period, grower period, and finisher period. The detailed design of the treatment for each stage of growth is described in Table 1.

Starter period. Four experimental diets, i.e., factorial of 2 nutrient densities x 2 enzyme levels were tested for the starter period. Two different densities of diets, i.e., High $(\mathrm{H})$ and Medium (M), were formulated. The nutrient content of the $\mathrm{H}$ density diet was formulated similar to the recommendation of the Indonesian Nasional Standard (SNI) for the pre-starter commercial layer chickens with the density of $70.7 \mathrm{~g}$ crude protein/Mcal
(BSN, 2016a). The $\mathrm{M}$ density was formulated similar to the SNI recommendation for grower commercial layer chickens with the density of $66.1 \mathrm{~g}$ crude protein/Mcal (BSN, 2016b). The ingredients composition and nutrient contents of the diets are shown in Table 2. Each diet was either supplemented with or without BS4 enzyme (30 Units of saccharification $/ \mathrm{kg}$ diet). The dose has been reported to be effective in increasing nutrients digestibility of diets in laying hens (Sinurat et al., 2014) and broilers (Sinurat et al., 2015).

Each diet was fed to 10 pens of KUB chickens with 11 birds/pen from $1 \mathrm{~d}$ to $28 \mathrm{~d}$ old. The birds' performances, i.e., feed intake, body weight gain, and liveability, were measured.

Grower period. Three diets with different densities, i.e., High (H), Medium (M), and Low (L), were formulated. The nutrient content of the $\mathrm{H}$ and $\mathrm{M}$ densities was similar to those in the starter period. The low-density diet was formulated similar to the recommendation of the SNI for grower diets for commercial layer chickens with the density of $59.3 \mathrm{~g}$ crude protein/Mca (BSN, 2016c). Six dietary treatments, i.e., factorial of 3 densities (H-M, M-M, and M-L) x 2 enzyme levels (without and with enzyme supplementation) were tested. Birds fed with H-M were fed with the $\mathrm{H}$ density diet during the starter period, followed by $\mathrm{M}$ density during the grower period. Birds fed with M-M were fed with the M density diet during the starter and grower periods. Birds fed with M-L were fed with the M density diet during the starter period, followed by L density during the grower period. Each diet was either supplemented with or without BS4 enzyme, similar to the starter period.

The dietary treatments were fed to KUB chickens with 11 birds/pen from $29 \mathrm{~d}$ to $56 \mathrm{~d}$ old. The H-M treatment was given to 10 pens, while the M-M and $\mathrm{M}-\mathrm{L}$ treatments were given to 5 pens, respectively. The performances of the birds, i.e., feed intake, body weight gain, and liveability, were measured.

Finisher period. During the finisher period, the factorial of 4 diet densities $\times 2$ enzyme levels were tested. The nutrient densities consist of H-M-L, H-M-M, M-M-L, and M-L-L. The H-M-L was a diet with $\mathrm{H}$ and $\mathrm{M}$ densi-

Table 1. The arrangement of enzyme supplementation and nutrient density during the starter, grower, and finisher period

\begin{tabular}{ccccc}
\hline No & $\begin{array}{c}\text { Enzyme } \\
\text { supplemented }\end{array}$ & Starter & Grower & Finisher \\
\hline 1 & Without & High & Medium & Low \\
2 & Without & High & Medium & Medium \\
3 & Without & Medium & Medium & Low \\
4 & Without & Medium & Low & Low \\
5 & With & High & Medium & Low \\
6 & With & High & Medium & Medium \\
7 & With & Medium & Medium & Low \\
8 & With & Medium & Low & Low \\
\hline
\end{tabular}

Note: The high, medium, and low density diet was formulated with a density of $70.7 \mathrm{~g}$ crude protein/Mcal, $66.1 \mathrm{~g}$ crude protein/Mcal, and $59.3 \mathrm{~g}$ crude protein/Mcal, respectively. 
Table 2. The composition and nutrient contents of the experimental diets

\begin{tabular}{|c|c|c|c|}
\hline \multirow{2}{*}{ Feed ingredients } & \multicolumn{3}{|c|}{ Nutrient density } \\
\hline & Low & Medium & High \\
\hline Maize, \% & 54.3 & 56.1 & 50.6 \\
\hline Wheat polard, $\%$ & 15.00 & 10 & 10 \\
\hline Palm-kernel cake, $\%$ & 8.50 & 7 & 5 \\
\hline Soybean meal, \% & 17.19 & 20.77 & 26.52 \\
\hline Vegetable oil, \% & 0.500 & 0.24 & 2.03 \\
\hline Meat and bone meal, \% & 1.00 & 4.35 & 4.3 \\
\hline Limestone, $\%$ & 1.880 & 0.89 & 0.86 \\
\hline Lysine, $\%$ & 0.020 & 0 & 0 \\
\hline Mono Calcium Phosphate, \% & 1.00 & 0 & 0 \\
\hline Methionine, $\%$ & 0.100 & 0.11 & 0.19 \\
\hline Salt, \% & 0.200 & 0.2 & 0.2 \\
\hline Vitamin-mineral premixes, $\%$ & 0.31 & 0.31 & 0.31 \\
\hline Total, $\%$ & 100 & 100 & 100 \\
\hline Price, (IDR/kg) & 5153 & 5407 & 5739 \\
\hline \multicolumn{4}{|l|}{ Nutrient composition*: } \\
\hline Dry matter, \% & $87.9(88.2)$ & $87.6(87.5)$ & $88.9(86.0)$ \\
\hline Crude fibre, $\%$ & $4.86(4.56)$ & $4.36(4.36)$ & $4.33(3.55)$ \\
\hline Crude protein $(\mathrm{CP}), \%$ & $16.0(16.8)$ & $18.5(19.3)$ & $20.5(21.13)$ \\
\hline Metabolizable energy, kcal/kg & 2700 & 2800 & 2900 \\
\hline Nutrient density, g CP/Mcal ME & 59.3 & 66.1 & 70.7 \\
\hline Lysine, $\%$ & $0.739(0.82)$ & $0.900(0.96)$ & $1.000(1.14)$ \\
\hline Methionine, \% & $0.355(0.24)$ & $0.428(0.24)$ & $0.500(0.25)$ \\
\hline Metionine + Cystine, $\%$ & $0.600(0.40)$ & $0.700(0.42)$ & $0.800(0.43)$ \\
\hline Threonine, $\%$ & $0.583(0.59)$ & $0.674(0.66)$ & $0.750(0.77)$ \\
\hline Tryptophan, \% & 0.190 & 0.210 & 0.236 \\
\hline Calcium (Ca), \% & $1.10(0.78)$ & $0.90(0.74)$ & $0.90(1.38)$ \\
\hline Total Phosphorous (P), \% & $0.68(0.85)$ & $0.63(0.88)$ & $0.64(0.89)$ \\
\hline Available Phosphorous, \% & 0.40 & 0.35 & 0.35 \\
\hline
\end{tabular}

Note: Numbers in brackets ( ) are results of laboratory analyses; MCal= $1000 \mathrm{kcal}$. The high, medium, and low density diet was formulated with a density of $70.7 \mathrm{~g} \mathrm{CP} / \mathrm{Mcal}, 66.1 \mathrm{~g} \mathrm{CP} / \mathrm{Mcal}$, and $59.3 \mathrm{~g} \mathrm{CP} / \mathrm{Mcal}$, respectively.

ties given for the starter and grower period, followed by $\mathrm{L}$ density for the finisher period. The H-M-M was a diet with $\mathrm{H}$ and $\mathrm{M}$ densities given for the starter and grower period, followed by the $\mathrm{M}$ density diet for the finisher period. The M-M-L was a diet with M density given for the starter and grower period, followed by L density for the finisher period. Each diet was either supplemented with or without BS4 enzyme, similar to the starter period.

The dietary treatments were fed to KUB chickens from $57 \mathrm{~d}$ to $84 \mathrm{~d}$ old with 5 replicates per treatment. The birds' performances, i.e., feed intake, body weight gain, and liveability, were measured.

\section{Variables and Data Analyses}

The performances of the birds (feed intake, body weight gain, and liveability) were measured for starter (1-28 d), grower (29-56 d), finisher period (57-84 d), and the whole period (1-84 d of age). At the end of the trial, one male and one female chicken were taken from each pen and slaughtered to evaluate the effects of the treatments on the carcass yield, abdominal fat levels, and liver weight. Chickens were slaughtered by draining the blood from the jugular vein with a sharp knife. The weights of the proventriculus and gizzard, the length of the duodenum, jejunum, and ileum, were also measured. Data of male and female chickens were pooled and not presented separately.

At the end of the feeding trial, one cockerel from each pen was removed to individual wire cages to measure the dry matter digestibility and metabolizable energy of the feed in a total collection method. Each day, the birds were fed 2 hours with $110 \mathrm{~g} / \mathrm{bird} / \mathrm{d}$ of the test diet for 3 days, followed by fasting for $24 \mathrm{~h}$. The following day $\left(4^{\text {th }}\right.$ day), the experimental birds were fed with 110 $\mathrm{g} / \mathrm{bird} / \mathrm{d}$ of test diet for $2 \mathrm{~h}$, and a tray was placed underneath the cage. The feed intake was measured, and the excreta were collected and dried in an oven $\left(70{ }^{\circ} \mathrm{C}\right)$ every day, and this procedure was repeated for 4 consecutive days. Dried excreta were pooled and weighed. The dry matter and gross energy were measured in a laboratory. The AME was calculated following the formula:

$$
\operatorname{AME}(\mathrm{kcal} / \mathrm{g})=((\mathrm{Gef} \times \mathrm{X})-(\mathrm{Gexc}-\text { Gend })) / \mathrm{X}
$$

where Gef is the gross energy of the feed (kcal/g); Gexc is the total gross energy voided in the excreta (kcal); $\mathrm{X}$ is the weight of the feed consumed (g). The dry matter digestibility (\%) was calculated with a similar formula. 
AME intake was calculated by multiplying the feed intake (1-84 d) with the AME of the feed and the AME efficiency ratio (AMEER) was calculated by dividing the total AME intake with the body weight gain during the trial.

The income over feed cost (IOFC) was calculated by subtracting the selling value of the chickens (the price of chicken $/ \mathrm{kg} x$ weight of chicken) with the cost of feed consumed (the price of feed $x$ total amount of feed consumed from 1 to $84 \mathrm{~d}$ ). The price of feed without enzyme was IDR 5739/kg, IDR 5407/kg, and IDR 5153/ $\mathrm{kg}$, for the high-, medium- and low densities diets, respectively. Feed supplemented with enzyme was IDR $50 / \mathrm{kg}$ more expensive than feed without enzyme, and the selling price of the chicken was IDR $35000 / \mathrm{kg}$.

All data were subject to analyses of variance (ANOVA) in a factorial design. Data on performance during the starter period (1- $28 \mathrm{~d}$ ) were analyzed in 2 (nutrient density) × 2 (enzyme supplement) factorial design, and data on performance during grower (29-56 d) were analyzed in 3 (nutrient density) x 2 (enzyme supplement) factorial design. Data on performance during the finisher period (57-84 d), and performance for the whole period (1-84 d), dry matter digestibility, AME and AME Efficiency Ratio (AMEER), carcass yield, and gastrointestinal tract size was analyzed in 4 (nutrient density) x 2 (enzyme supplement) factorial design. Differences between treatments were calculated by Duncan's multiple range tests if the ANOVA was significant $(\mathrm{p}<0.05)$.

\section{RESULTS}

\section{Growth Performances of KUB Chickens during Starter Period}

The performances of KUB chickens during the starter period (1-28 d) are presented in Table 3. Body weights of experimental chickens at one day old in the beginning of treatment were similar. Body weight gains of the experimental chickens during the starter period were similar. There were no significant effects of nutrient densities, enzyme supplementation, and interactions between nutrient densities (ND) and enzyme supplementation on body weight gain (BWG).
Feed intake was not significantly affected by the nutrient densities or enzyme supplementation. However, there was a significant $(\mathrm{p}<0.05)$ interaction between nutrient densities and enzyme supplementation on feed intakes of experimental KUB chicks. Supplementation of the BS4 enzyme into the highdensity diet did not affect the feed intake but significantly $(p<0.05)$ reduced the feed intake of chicks fed the medium-density diet.

The nutrient density of the diet did not significantly affect the FCR of the experimental chicks. However, enzyme supplementation in the diet during the starter period significantly $(p<0.05)$ affected the FCR of experimental chicks. In addition, there was an interaction effect of nutrient density and enzyme supplementation in the diet on FCR. Supplementation of enzymes into the high-density diet did not significantly affect the FCR, while supplementation into the medium density diet improved the FCR significantly $(\mathrm{p}<0.05)$. The best FCR was achieved when the KUB chickens were fed medium nutrient density diet supplemented with BS4 enzyme. During the starter period, the livability of the KUB chickens was not significantly affected by the treatments with nutrient density and enzyme supplementation in the feed.

\section{Growth Performance of KUB Chickens during Grower Period}

The performances of the KUB chickens during the grower period ( 29 to 56 days old) are presented in Table 4. Nutrient density significantly affected $(p<0.05)$ bodyweight gain. Enzyme supplementation in the ration did not affect the body weight gain of experimental chickens during the grower period. However, the body weight gain was significantly $(p<0.05)$ affected by the interaction between nutrient density and enzyme supplementation. In the chickens fed ration without enzyme supplementation during the grower period, the heaviest body weight gain (452 g) was reached by chickens fed the H-M density diet. This BWG was not significantly different from chickens fed the M-M density diet (402 g) but significantly different $(\mathrm{p}<0.05)$ from chickens fed the M-L diet (395 g). However, when the enzyme was supplemented in the diet, the heaviest BWG was

Table 3. Performances of KUB chickens during starter period (1-28 day) as were affected by nutrient densities and enzyme supplementation

\begin{tabular}{lcccccr}
\hline $\begin{array}{l}\text { Nutrient } \\
\text { densities }\end{array}$ & Enzyme & $\begin{array}{c}\text { Day old BW } \\
(\mathrm{g} / \mathrm{bird})\end{array}$ & BWG $(\mathrm{g} / \mathrm{bird})$ & $\begin{array}{c}\text { Feed intake } \\
(\mathrm{g} / \mathrm{bird})\end{array}$ & FCR & Livability $(\%)$ \\
\hline High & Without & $31.7 \pm 1.7$ & $255.4 \pm 19.3$ & $617.4 \pm 81.4^{\mathrm{a}}$ & $2.41 \pm 0.20^{\mathrm{a}}$ & $99.1 \pm 2.9$ \\
Medium & Without & $30.3 \pm 2.0$ & $248.4 \pm 17.0$ & $599.4 \pm 43.1^{\mathrm{ab}}$ & $2.42 \pm 0.23^{\mathrm{a}}$ & $96.4 \pm 8.8$ \\
High & With & $29.9 \pm 2.3$ & $255.6 \pm 11.0$ & $592.0 \pm 27.2^{\mathrm{ab}}$ & $2.32 \pm 0.08^{\mathrm{ab}}$ & $99.1 \pm 2.9$ \\
Medium & With & $31.1 \pm 2.3$ & $256.4 \pm 8.9$ & $559.5 \pm 8.6^{\mathrm{b}}$ & $2.19 \pm 0.10^{\mathrm{b}}$ & $100.0 \pm 0.0$ \\
-Value & & & & & \\
Nutrient density (ND) & & 0.96 & 0.71 & 0.41 & 0.83 & 0.55 \\
Enzyme (E) & & 0.56 & 0.3 & 0.12 & 0.03 & 0.08 \\
ND E E & & 0.09 & 0.43 & 0.01 & 0.03 & 0.55 \\
\hline
\end{tabular}

Note: Means in the same column with different superscripts differ significantly $(\mathrm{p}<0.05)$. BW= body weight; $B W G=$ body-weight gain; FCR= Feedconversion ratio. 
Table 4. Performances of KUB chickens during grower period (age 29-56 days) as were affected by nutrient densities and enzyme supplementation

\begin{tabular}{lccccc}
\hline \multicolumn{1}{c}{ Nutrient densities } & Enzyme & BWG (g/bird) & Feed intake $(\mathrm{g} / \mathrm{bird})$ & FCR & Livability $(\%)$ \\
\hline High-Medium & Without & $452 \pm 27^{\mathrm{a}}$ & $1780 \pm 80^{\mathrm{ab}}$ & $3.93 \pm 0.29^{\mathrm{b}}$ & $100.0 \pm 0.0$ \\
Medium-Medium & Without & $402 \pm 46^{\mathrm{a}}$ & $1657 \pm 154^{\mathrm{c}}$ & $4.20 \pm 0.81^{\mathrm{ab}}$ & $96.4 \pm 13.8$ \\
Medium-Low & Without & $395 \pm 38^{\mathrm{b}}$ & $1622 \pm 77^{\mathrm{cd}}$ & $4.13 \pm 0.35^{\mathrm{b}}$ & $98.2 \pm 4.1$ \\
High-Medium & With & $441 \pm 35^{\mathrm{a}}$ & $1704 \pm 136^{\mathrm{bc}}$ & $3.87 \pm 0.29^{\mathrm{b}}$ & $99.1 \pm 2.9$ \\
Medium-Medium & With & $456 \pm 24^{\mathrm{a}}$ & $1594 \pm 94^{\mathrm{d}}$ & $3.50 \pm 0.20^{\mathrm{c}}$ & $100.0 \pm 0.0$ \\
Medium-Low & With & $406+34^{\mathrm{b}}$ & $1857 \pm 83^{\mathrm{a}}$ & $4.47 \pm 0.33^{\mathrm{a}}$ & $98.2 \pm 4.1$ \\
p-Value & & & & & 0.02 \\
Nutrient density (ND) & & 0.01 & 0.03 & 0.30 & 0.72 \\
Enzyme (E) & & 0.31 & 0.002 & 0.02 & 0.61 \\
ND x E & & 0.05 & & & 0.00 \\
\hline
\end{tabular}

Note: Means in the same column with different superscripts differ significantly $(\mathrm{p}<0.05)$. BWG= body-weight gain; FCR= Feed-conversion ratio.

achieved by chickens fed with the M-M density diet (456 g). In the chickens fed diet supplemented with BS4 enzyme, chickens fed with M-M density diet had similar BWG with chickens fed the H-M density diet $(441 \mathrm{~g})$ but significantly higher $(\mathrm{p}<0.05)$ than chickens fed the M-L density diet (406 g). The highest BWG was found in chickens fed ration with M-M nutrient densities supplemented with enzyme (456 g/bird), followed by the chickens fed ration with $\mathrm{H}-\mathrm{M}$ nutrient densities without enzyme supplementation (452g/bird) and chickens fed ration with $\mathrm{H}-\mathrm{M}$ nutrient densities with enzyme supplementation (441 g/bird).

Feed intake of birds during the grower period was significantly $(p<0.01)$ affected by the nutrient density. There was no significant effect of enzyme supplementation in the diet on the feed intakes of experimental birds. However, there was a significant interaction effect between nutrient density and enzyme supplementation on feed intake. When feed was not supplemented with enzyme, the lowest feed intake was found in chickens fed the M-L density diet (1622 g/bird). Feed intake was significantly $(\mathrm{p}<0.05)$ higher in birds fed the H-M density diet $(1780 \mathrm{~g} /$ bird $)$ than those fed M-M and M-L densities diets. However, when the feed was supplemented with enzyme, the lowest feed intake was found in chickens fed the M-M density diet (1594 g/bird). The highest feed intake was found in chickens fed M-L densities diets $(1857 \mathrm{~g} /$ bird $)$ that was significantly $(p<0.05)$ higher compared to chickens fed H-M (1704 g/bird). In general, the highest feed intake was found in chickens fed diet with M-L nutrient densities supplemented with enzyme (1857 g/bird). The second highest feed intake was found in chickens fed the diet with H-M nutrient densities without enzyme supplementation (1780 g/ bird), and the third was found in chickens fed the diet with H-M nutrient densities with enzyme supplementation (1704 g/bird).

During the grower period, the FCR of experimental chickens was significantly affected by the nutrient density. However, the enzyme supplementation did not affect the FCR. There was a significant interaction effect of nutrient density and enzyme supplementation in the diet on FCR during the grower period $(p<0.05)$. The best FCR (3.50) was found in the chickens fed the M-M nutrient density diet with enzyme supplementation. In general, the livability of the chickens during the grower period was good and was not significantly affected by treatments.

\section{Growth Performance of KUB Chickens during Finisher Period}

The growth performances of the KUB chickens during the finisher period are presented in Table 5. Nutrient density and enzyme supplementation in the diet did not significantly affect the body weight gain of experimental chickens during the finisher period. In addition, there was no interaction effect between nutrient density and enzyme supplementation on the bodyweight of experimental chickens.

During the finisher period, nutrient density significantly affected experimental chickens' feed intake $(p<0.01)$. However, enzyme supplementation did not affect the feed intake of the experimental chickens. In addition, there was no interaction effect between nutrient density and enzyme supplementation. The highest feed intake (2556 g/bird) was found in chickens fed H-M-L nutrient density diet without enzyme supplementation, followed by chickens fed M-L-L nutrient density diet with enzyme supplementation (2527 g/bird), chickens fed M-L-L nutrient density without enzyme supplementation (2507 g/bird) that were significantly higher $(\mathrm{p}<0.05)$ than those chickens fed H-M-M nutrient density diet supplemented with enzyme (2346 g/bird), and followed by chickens fed M-M-L nutrient density diet without enzyme supplementation (2324 g/bird), followed by chickens fed M-M-L nutrient density diet with enzyme supplementation (2313 g/bird), and chickens fed H-M-M nutrient density diet without enzyme supplementation (2278 g/bird).

During the finisher period, the FCR of experimental chickens was similar and was not affected by nutrient density and enzyme supplementation. In addition, there were no significant interaction effects of nutrient density and enzyme supplementation on the FCR of experimental chickens during the finisher period. During the finisher period, the FCR in the experimental KUB chickens ranged from the lowest level (4.07) in 
M-M-L with enzyme supplementation to the highest level (4.92) in H-M-L nutrient density without enzyme supplementation.

The livabilities of experimental KUB chickens during the finisher period were good and were not significantly affected by the treatments of nutrient density and enzyme supplementation in the diet.

\section{Growth Performance of KUB Chickens from 1-84 Days}

The growth performances of the KUB chickens from 1 to 84 days of age are presented in Table 6 . The body weight gain and the livability of the KUB chickens from 1 to $84 \mathrm{~d}$ old were not significantly affected by the nutrient density, enzyme supplementation. There was no interaction effect between nutrient density and enzyme supplementation on the growth performances of KUB chickens from 1 to $84 \mathrm{~d}$ old.

The feed intake was significantly $(p<0.05)$ affected by the nutrient density of the ration. However, the feed intake was not significantly affected by the enzyme supplementation. In addition, there was no interaction effect of nutrient density and enzyme supplementation on the feed intake during 84 days of raising KUB chickens. The highest feed intake (4956 g/bird) was found in birds fed the high-density starter diet followed by medium-density grower diet and the low-density finisher diet (H-M-L) and was significantly different from those fed medium-density starter diet followed by mediumdensity grower diet and the low-density finisher diet (M-M-L).

The feed conversion ratio of experimental KUB chickens was not affected by the nutrient density and enzyme supplementation. However, there were significant interaction effects of nutrient density and enzyme supplementation in the diet on the FCR of experimental KUB chickens during 84 days of rearing $(\mathrm{p}<0.05)$. When the feed was not supplemented with the enzyme, the best FCR (3.77) was found by feeding chickens with the high-density starter diet followed by the mediumdensity grower and medium-density finisher diets (H-M-M). However, when feed was supplemented with the enzyme, the best FCR (3.48) was found by feeding the medium-density starter diet followed by the medium-density grower diet and the low-density finisher diet (M-M-L). The livability of all experimental KUB chickens during 84 days of rearing was good and was not affected by the nutrient density and enzyme supplementation.

Table 5. Performances of KUB chickens during grower period (age 57-84 days) as were affected by nutrient densities and enzyme supplementation

\begin{tabular}{lccccc}
\hline \multicolumn{1}{c}{ Nutrient densities } & Enzyme & BWG $(\mathrm{g} / \mathrm{bird})$ & Feed intake $(\mathrm{g} / \mathrm{bird})$ & FCR & Livability $(\%)$ \\
\hline High-Medium-Low & Without & $526 \pm 60$ & $2556 \pm 132^{\mathrm{a}}$ & $4.92 \pm 0.69$ & $96.4 \pm 5.0$ \\
High-Medium-Medium & Without & $508 \pm 78$ & $2278 \pm 43^{\mathrm{b}}$ & $4.56 \pm 0.73$ & $96.4 \pm 4.5$ \\
Medium-Medium-Low & Without & $516 \pm 72$ & $2324 \pm 297^{\mathrm{b}}$ & $4.53 \pm 0.40$ & $96.4 \pm 5.0$ \\
Medium-Low-Low & Without & $575 \pm 104$ & $2507 \pm 80^{\mathrm{a}}$ & $4.49 \pm 0.90$ & $96.4 \pm 8.2$ \\
High-Medium-Low & With & $558 \pm 47$ & $2413 \pm 132^{\mathrm{a}}$ & $4.35 \pm 0.39$ & $98.2 \pm 4.1$ \\
High-Medium-Medium & With & $536 \pm 68$ & $2346 \pm 84^{\mathrm{b}}$ & $4.44 \pm 0.60$ & $98.2 \pm 4.1$ \\
Medium-Medium-Low & With & $571 \pm 41$ & $2313 \pm 152^{\mathrm{b}}$ & $4.07 \pm 0.48$ & $94.5 \pm 5.0$ \\
Medium-Low-Low & With & $563 \pm 26$ & $2527 \pm 57^{\mathrm{a}}$ & $4.58 \pm 0.19$ & $100.0 \pm 0.0$ \\
p-Value & & & & & 0.64 \\
Nutrient density (ND) & & 0.46 & 0.003 & 0.16 & 0.67 \\
Enzyme (E) & & 0.22 & 0.72 & 0.41 & 0.39 \\
ND x E & & 0.71 & & 0.57 & 0.67 \\
\hline
\end{tabular}

Note: Means in the same column with different superscripts differ significantly $(\mathrm{p}<0.05)$. BWG= body-weight gain; FCR= Feed-conversion ratio.

Table 6. Performances of KUB chickens from 1-84 day as were affected by nutrient densities and enzyme supplementation

\begin{tabular}{lccccc}
\hline \multicolumn{1}{c}{ Nutrient densities } & Enzyme & BWG $(\mathrm{g} / \mathrm{bird})$ & Feed intake $(\mathrm{g} / \mathrm{bird})$ & FCR & Livability $(\%)$ \\
\hline High-Medium-Low & Without & $1248 \pm 116$ & $4956 \pm 229^{\mathrm{a}}$ & $4.07 \pm 0.40^{\mathrm{a}}$ & $96 \pm 5$ \\
High-Medium-Medium & Without & $1225 \pm 78$ & $4603 \pm 54^{\mathrm{bc}}$ & $3.77 \pm 0.28^{\mathrm{ab}}$ & $96 \pm 5$ \\
Medium-Medium-Low & Without & $1159 \pm 77$ & $4612 \pm 437^{\mathrm{c}}$ & $3.99 \pm 0.35^{\mathrm{a}}$ & $93 \pm 12$ \\
Medium-Low-Low & Without & $1225 \pm 90$ & $4696 \pm 172^{\mathrm{ab}}$ & $3.85 \pm 0.29^{\mathrm{ab}}$ & $95 \pm 5$ \\
High-Medium-Low & With & $1253 \pm 54$ & $4730 \pm 300^{\mathrm{a}}$ & $3.78 \pm 0.19^{\mathrm{ab}}$ & $98 \pm 4$ \\
High-Medium-Medium & With & $1234 \pm 68$ & $4619 \pm 101^{\mathrm{bc}}$ & $3.75 \pm 0.27^{\mathrm{ab}}$ & $98 \pm 4$ \\
Medium-Medium-Low & With & $1285 \pm 31$ & $4462 \pm 243^{\mathrm{c}}$ & $3.48 \pm 0.24^{\mathrm{b}}$ & $95 \pm 5$ \\
Medium-Low-Low & With & $1246 \pm 63$ & $4947 \pm 88^{\mathrm{ab}}$ & $4.05 \pm 0.15^{\mathrm{a}}$ & $98 \pm 4$ \\
p-Value & & & & & \\
Nutrient density (ND) & & 0.86 & 0.01 & 0.23 & 0.49 \\
Enzyme (E) & & 0.10 & 0.72 & 0.09 & 0.04 \\
ND x E & & 0.25 & 0.13 & & 0.98 \\
\hline
\end{tabular}

Note: Means in the same column with different superscripts differ significantly $(\mathrm{p}<0.05)$. BWG= body-weight gain; FCR= Feed-conversion ratio. 


\section{Dry Matter Digestibility, AME and AME Efficiency Ratio (AMEER)}

Dry matter (DM) digestibility and metabolizable energy (AME) of the diets are presented in Table 7 . The DM digestibility and the AME were not significantly affected by the interaction between ND and E. However, the DM digestibility and the AME of the diet were significantly $(p<0.01)$ affected by nutrient density but not by the enzyme supplementation. High nutrient density has the lowest DM digestibility, and significantly $(p<0.05)$ lower than the DM digestibility of the low- and medium-density diets. The determined AME values of the diets have a similar trend but were higher than the calculated values used in the diet formulation. The determined AME values of low-, medium-, and high-density diets were 2883, 2925, and $3009 \mathrm{Kcal} / \mathrm{kg}$, respectively.

The total AME intake and AME efficiency ratio (AMEER) during the experimental period (1-84 d) are presented in Table 8. The AME intake was not significantly affected by the interaction between ND and

Table 7. Dry matter digestibility and apparent metabolizable energy of feed with different nutrient densities and enzyme supplementation

\begin{tabular}{lcc}
\hline & $\begin{array}{c}\text { Dry matter } \\
\text { digestibility }(\%)\end{array}$ & $\begin{array}{c}\text { AME } \\
(\mathrm{kcal} / \mathrm{kg})\end{array}$ \\
\hline Nutrient density: & & \\
$\quad$ Low & $70.38 \pm 1.43^{\mathrm{a}}$ & $2883 \pm 59^{\mathrm{b}}$ \\
$\quad$ Medium & $70.23 \pm 1.84^{\mathrm{a}}$ & $2925 \pm 73^{\mathrm{b}}$ \\
$\quad$ High & $67.14 \pm 1.67^{\mathrm{b}}$ & $3009 \pm 63^{\mathrm{a}}$ \\
Enzyme supplementation: & & \\
$\quad$ With & $70.0 \pm 2.54$ & $2937 \pm 89$ \\
$\quad$ Without & $69.8 \pm 1.88$ & $2942 \pm 79$ \\
p-values & & \\
$\quad$ Enzyme supplementation (E) & 0.73 & 0.83 \\
$\quad$ Nutrient density (D) & 0.00 & 0.00 \\
Ex D & 0.79 & 0.79 \\
\hline
\end{tabular}

Note: Means in the same column and factor with different superscripts differ significantly $(\mathrm{p}<0.05)$. AME $=$ apparent metabolizable energy.
E. However, it was significantly $(p<0.05)$ affected by nutrient density but not by enzyme supplementation. Chickens fed the H-M-L diets consumed the highest dietary $\operatorname{AME}(14,199 \mathrm{Mcal} / \mathrm{bird})$, and chickens fed the M-M-L diets consumed the lowest dietary AME (13,237 Mcal/bird). The AMEER was not significantly affected by the interaction between ND and E. However, the AMEER was significantly $(p<0.05)$ affected by enzyme supplementation but not by nutrient density. Chickens fed with a diet supplemented with enzyme (10.58 $\mathrm{Mcal} / \mathrm{g}$ BWG) were more efficient in converting dietary energy to body weight than those fed diets without enzyme supplementation (11.26 Mcal/g BWG).

\section{Carcass Yield and Gastrointestinal Tract Size}

Data on the carcass yield, abdominal fat weight, and liver weight of KUB chickens are presented in Table 9. The results showed that the percentage of carcass yield, abdominal fat level, and relative liver weight were

Table 8. Total AME intake (Mcal/bird) and AME efficiency ratio of KUB chickens fed with different nutrient densities and enzyme supplementation

\begin{tabular}{lll}
\hline & $\begin{array}{c}\text { AME intake } \\
\text { (Mcal/bird) }\end{array}$ & $\begin{array}{c}\text { AMEER } \\
\text { (Mcal/g BWG) }\end{array}$ \\
\hline Nutrient density: & & \\
$\quad$ High-Medium-Low & $14199 \pm 810^{\mathrm{a}}$ & $11.22 \pm 0.93$ \\
High-Medium-Medium & $13654 \pm 300^{\text {ab }}$ & $10.87 \pm 0.77$ \\
$\quad$ Medium-Medium-Low & $13237 \pm 928^{\mathrm{b}}$ & $10.36 \pm 1.61$ \\
$\quad$ Medium-Low-Low & $14055 \pm 401^{\mathrm{a}}$ & $11.22 \pm 0.62$ \\
Enzyme supplementation: & & \\
$\quad$ With & $13899 \pm 781$ & $11.26 \pm 0.90^{\mathrm{a}}$ \\
$\quad$ Without & $13673 \pm 703$ & $10.58 \pm 1.15^{\mathrm{b}}$ \\
p-values & & \\
$\quad$ Enzyme supplementation (E) & 0.28 & 0.029 \\
$\quad$ Nutrient density (D) & 0.01 & 0.148 \\
E x D & 0.243 & 0.053 \\
\hline
\end{tabular}

Note: Means in the same column and factor with different superscripts differ significantly $(\mathrm{p}<0.05)$. AME $=$ apparent metabolizable energy; AMEER= AME efficiency ratio.

Table 9. Carcass yield, abdominal fat, and liver weight of KUB chickens fed diets with different nutrient densities and enzyme supplementation

\begin{tabular}{|c|c|c|c|}
\hline & Carcass (\%BW) & Abdominal fat (\%BW) & Liver (\%BW) \\
\hline \multicolumn{4}{|l|}{ Nutrient density (ND) } \\
\hline High-Medium-Low & $68.50 \pm 2.29$ & $1.13 \pm 0.78$ & $2.13 \pm 0.41$ \\
\hline High- Medium- Medium & $68.52 \pm 2.57$ & $1.00 \pm 0.57$ & $2.10 \pm 0.29$ \\
\hline Medium-Medium-Low & $68.84 \pm 4.70$ & $1.24 \pm 1.14$ & $2.11 \pm 0.25$ \\
\hline Medium-Low-Low & $68.70 \pm 2.22$ & $0.98 \pm 0.65$ & $2.17 \pm 0.57$ \\
\hline \multicolumn{4}{|l|}{ Enzyme supplementation (E) } \\
\hline With & $68.39 \pm 3.81$ & $1.12 \pm 0.92$ & $2.13 \pm 0.49$ \\
\hline Without & $68.89 \pm 2.13$ & $1.06 \pm 0.69$ & $2.12 \pm 0.26$ \\
\hline \multicolumn{4}{|l|}{ p-Value } \\
\hline Nutrient density (ND) & 0.99 & 0.85 & 0.46 \\
\hline Enzyme (E) & 0.38 & 0.78 & 0.68 \\
\hline ND $\times E$ & 0.86 & 0.40 & 0.79 \\
\hline
\end{tabular}

Note: BW= body weight. 
not significantly affected by the interaction between ND and E, nutrient density, or enzyme supplementation.

The size of some gastrointestinal tracts of KUB chickens measured at the end of the experiment is shown in Table 10. The interaction between ND and E, nutrient density, or enzyme supplementation was not significantly affected by the proventriculus weight, gizzard weight, and duodenum length. However, the jejunum size was significantly $(p<0.05)$ affected by the nutrient density. The jejunum of chickens fed mediumlow-low (M-L-L) density diets $(55.0 \mathrm{~cm})$ and M-M-L density $(54.9 \mathrm{~cm})$ was significantly $(\mathrm{p}<0.05)$ longer than those fed H-M-M density diets $(49.1 \mathrm{~cm})$. Enzyme supplementation in the diet did not significantly affect the jejunum size. The ileum size was significantly $(p<0.05)$ affected by the enzyme supplementation in the diet. Chickens-fed diets supplemented with enzymes have a significant $(p<0.5)$ shorter ileum $(50.7 \mathrm{~cm})$ as compared with those fed diets without enzymes supplementation
$(54.1 \mathrm{~cm})$. Nutrient density did not significantly affect the ileum size.

\section{Income Over Feed Cost}

The effects of the treatments on the income over feed cost (IOFC) are shown in Figure 1. The interactions between the ND and E significantly $(p<0.05)$ affect the IOFC. The highest IOFC was obtained when the KUB chickens were fed the M-M-L density diets and supplemented with the enzyme (IDR 22311/bird). The lowest IOFC was obtained when the chickens were fed similar (M-M-L) density diets without enzyme supplementation.

\section{DISCUSSION}

Enzymes are known as biological products with a specific biochemical reaction such as breaking down a

Table 10. Gastrointestinal size of KUB chickens fed diets with different nutrient densities and enzyme supplementation

\begin{tabular}{|c|c|c|c|c|c|}
\hline & Proventriculus (g) & Gizard (g) & Duodenum $(\mathrm{cm})$ & Jejunum $(\mathrm{cm})$ & Ileum $(\mathrm{cm})$ \\
\hline \multicolumn{6}{|l|}{ Nutrient density } \\
\hline High-Medium-Low & $7.31 \pm 1.84$ & $2.79 \pm 0.49$ & $24.47 \pm 3.20$ & $54.88 \pm 5.80^{\mathrm{a}}$ & $52.94 \pm 6.61$ \\
\hline High-Medium-Medium & $6.92 \pm 1.66$ & $2.84 \pm 0.40$ & $24.27 \pm 2.37$ & $49.06 \pm 5.91^{\mathrm{b}}$ & $50.53 \pm 7.88$ \\
\hline Medium-Medium-Low & $6.52 \pm 1.73$ & $2.75 \pm 0.54$ & $25.53 \pm 3.66$ & $51.16 \pm 6.73^{\mathrm{ab}}$ & $52.16 \pm 7.63$ \\
\hline Medium-Low-Low & $7.06 \pm 1.87$ & $2.75 \pm 0.49$ & $25.88 \pm 3.60$ & $55.00 \pm 6.09^{\mathrm{a}}$ & $53.56 \pm 5.88$ \\
\hline \multicolumn{6}{|l|}{ Enzyme supplemention (E) } \\
\hline With & $6.99 \pm 1.72$ & $2.82 \pm 0.50$ & $24.57 \pm 3.26$ & $52.97 \pm 7.15$ & $54.09 \pm 7.31^{\mathrm{a}}$ \\
\hline Without & $6.91 \pm 1.84$ & $2.75 \pm 0.46$ & $25.58 \pm 3.21$ & $51.84 \pm 5.78$ & $50.70 \pm 6.43^{b}$ \\
\hline \multicolumn{6}{|l|}{ p-Value } \\
\hline Nutrient density (ND) & 0.56 & 0.88 & 0.42 & 0.02 & 0.56 \\
\hline Enzyme (E) & 0.86 & 0.98 & 0.17 & 0.69 & 0.04 \\
\hline $\mathrm{ND} \times \mathrm{E}$ & 0.33 & 0.53 & 0.49 & 0.61 & 0.50 \\
\hline
\end{tabular}

Note: Means in the same column and factor with different superscripts differ significantly $(\mathrm{p}<0.05)$.

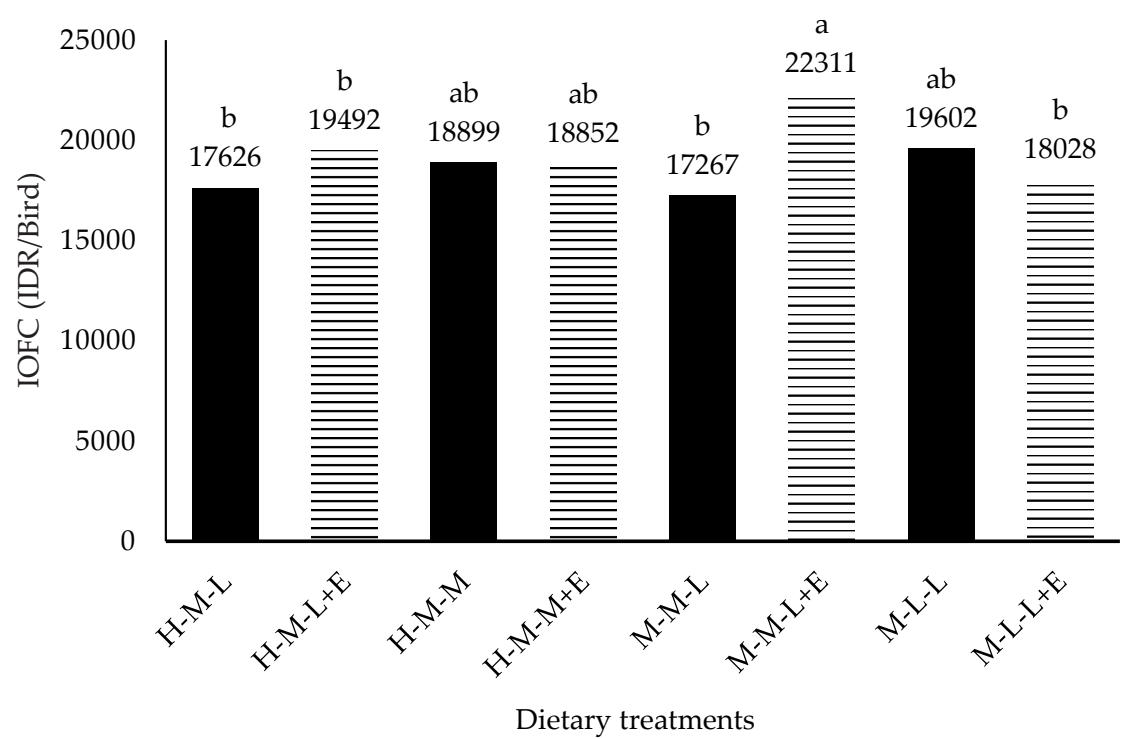

Figure 1. Income over feed cost gained after feeding KUB chickens fed diet with different densities and enzyme supplement from 1-84 days, without enzyme (๘), with enzyme (三). H-M-L= High-medium-low density diet; $\mathrm{H}-\mathrm{M}-\mathrm{M}=$ High-medium-low density diet; $\mathrm{M}-\mathrm{M}-\mathrm{L}=$ Medium-medium-low density diet; $\mathrm{M}-\mathrm{L}-\mathrm{L}=\mathrm{Medium}-$ low-low density diet; Different characters above the values show significantly difference $(\mathrm{p}<0.05)$. 
complex molecule structure become simple molecules structure. Although chickens naturally produce digestive enzymes endogenously, supplementation of exogenous enzymes in the commercial poultry feed is commonly practiced. The beneficial effect of dietary enzyme supplementation is normally pronounced in better efficiency of feed utilization as an effect of reduction in feed intake (Hajati, 2010), higher body weight gain (El-Kelawy et al., 2017), or the combination between feed intake reduction and body weight gain improvement (Amerah et al., 2017). The BS4 enzyme used in this experiment has been reported to increase dry matter, protein-digestibility, and the ME of palm kernel meal (Sinurat et al., 2013; 2015), ileal protein, and amino acids digestibility of fermented palm kernel cake (Sinurat et al., 2014). This is in line with results that showed that feeding chickens with lower nutrient levels achieved similar performances as those fed with nutrient density diets (Abudabos, 2012; Jabbar et al., 2021).

The bodyweight of the KUB chickens achieved in this experiment was higher than those reported by Puteri et al. (2020) at the same age. The effect of enzymes on the FCR in this trial, is consistently and significantly affected by the interaction between the enzyme supplementation and nutrient density during starter, grower, and finisher periods. This means that the enzyme supplementation has different effects on the FCR when the nutrient densities are different. Enzyme supplementation in the starter diet only effectively improves the FCR of medium-density diet significantly (10.5\% improvement), while supplementation of the enzyme in the high-density diet only slightly but not significantly improved the FCR (3.9\% improvement). This improvement resulted from the reduction in feed intake without altering the body weight gain (Table 3). Enzymes are well known to enhance the digestibility of low-quality feedstuffs; hence more nutrients available could be absorbed in the gastrointestinal tracts. Since the medium-density diet contains a higher level of low-quality feedstuff such as palm-kernel meal than the high-density diet (Table 2), the effect of adding enzymes in the medium-density diets was more pronounced than in the high-density diet. A similar finding was also reported in broiler chickens (Abudabos, 2012).

The classical theory stated that nutrient (especially energy) density is negatively correlated with the feed intake in poultry. However, breeding selection has evolved the physiological mechanism of feed intake control (Classen, 2017). The results of this trial did not show a clear effect of nutrient density on the feed intake, as shown by the significant interaction between enzyme supplement and nutrient density. During the starter period, feed intake was slightly lower in birds fed the medium-density diet than those fed the high-density diet. Kim et al. (2016) showed that the feed intake of broilers fed a high-density diet was lower than those fed a low-density diet. The feed intake responses of slowgrowing chickens to different density diets may differ from the fast-growing chickens. Sun et al. (2017) and Wang et al. (2013) showed that the feed intake of slowgrowing broilers was not different when fed a mediumor a high-density diet.
The significant interactions between nutrient density and enzyme supplementation in the diet on the performance, especially the FCR of the KUB chickens, suggest that different feeding methods should be applied when the enzyme is supplemented. Based on the performance from 1-84 d, the KUB chickens should be fed with a high-density starter diet followed by a medium density diet for the grower and finisher period (H-M-M) when the enzyme was not supplemented. However, a medium-density diet during starter and grower periods followed by a low-density finisher diet (M-M-L) should be fed when the enzyme was supplemented.

Carcass percentage, relative abdominal fat, and liver weight were not affected by treatments. Results on broilers (Zhai et al., 2013; Kim et al., 2016) or slow-growing chickens (Sun et al., 2017) also showed that carcass yield and abdominal fat level were not affected by the nutrient density of the feed. Hajati (2010) reported that dietary enzyme enhanced the carcass percentages but not the abdominal fat levels and liver weights of broilers. On the other hand, Hussein et al. (2020) showed no effect of enzyme supplementation on carcass and fat weight. Still, the liver weight was increased when the enzyme was supplemented into a low energy diet but not into a normal or higher energy diet.

Among the gastrointestinal tracts, the length of the jejunum was significantly affected by nutrient density, and the length of the ileum was significantly affected by enzyme supplementation. The results showed that chickens fed a lower density diet (M-L-L) have a longer jejunum size than those fed with higher density diets (H-M-M). This finding is in agreement with Hussein et al. (2020). The results also found that enzyme supplementation produced shorter ileum. This is in agreement with Kalmendal \& Tauson (2012) but contradicting to the finding of Hussein et al. (2020). Increasing the size of intestinal organs normally indicate their higher activities. A shorter jejunum size of chickens fed a high-density diet may indicate that the digestion and nutrient absorption is easier than the low-density diet in the jejunum. A shorter ileum size may indicate that the absorption of nutrients was easier in the ileum due to enzyme supplementation. This is supported by findings that a lower viscosity of ileal digesta in chickens fed the dietary enzyme (Balasubramanian et al., 2018). The results also showed that birds fed with M-M-L supplemented with enzyme have shorter ileum and best FCR among the treatments.

The determined AME values of the diets were higher than the calculated values used in the diet formulation. The determined AME values of low-, medium-, and high-density diets were 2883, 2925, and $3009 \mathrm{Kcal} /$ $\mathrm{kg}$, respectively, while the calculated AME values were 2700, 2800, and $2900 \mathrm{kcal} / \mathrm{kg}$ (Table 2), respectively. The AME values used in the diet formulation were based on values usually obtained from hybrid or fast growth chickens which may differ from the local or slowgrowth chickens. Zaefarian et al. (2015) showed that bird genetics might be another factor causing the variability in nutrient digestibility.

The AMEER is an indicator of the conversion of dietary energy to bodyweight gain. This study showed 
that nutrient density affected the AME intake but not the AMEER. This finding was contradicted with finding on broilers (Shu-Biao et al., 2019). Information on AMEER on slow growth chickens and fast growth chickens is scant. Therefore, no explanation could be given for this discrepancy. The KUB chickens less efficient in converting energy to body weight gain with the AMEER varied from 10.22-11.22 Mcal/g BWG as compared to the broiler chickens with the AMEER varied from 4.41-4.56 $\mathrm{Mcal} / \mathrm{g} \mathrm{BW}$ (Shu-Biao et al., 2019).

Although the AME of the diet and the AME intake was not significantly affected by enzyme supplementation, the AMEER was improved $6.4 \%$ by enzyme supplementation. This indicates that the dietary enzyme may not only increase nutrient digestibility of feed as commonly declared but may also increase the energy anabolism or conversion of metabolized energy into bodyweight or body cells. However, further study needs to prove this hypothesis. Abdallh et al. (2020) also reported that enzyme supplementation improved the efficiencies of ME use for body energy or energy retention in broilers.

Income over feed cost (IOFC) is a simple indicator of the profitability of a poultry farm. Increasing the nutrient density and supplementation of the enzyme into a diet increased the price of feed. However, the IOFC is not affected by the feed price only but also the FCR. In this trial, the highest IOFC (IDR 22,311/bird) was obtained when the birds were fed diet H-M-L and supplemented with the enzyme. This treatment also produced the lowest FCR. El-Kelawy et al. (2017) also showed an increase in the net revenue of broilers fed with an enzyme supplemented diet.

The Indonesian Nasional Standard (SNI) recommends the nutrient density for local chickens age 0 to 4 weeks was $65.5 \mathrm{~g} \mathrm{CP} / \mathrm{Mcal} \mathrm{ME}$ (BSN, 2013a). However, based on the performance achieved in this experiment, the best nutrient density for KUB chickens age 0 to 4 weeks was $70.7 \mathrm{~g} \mathrm{CP} /$ Mcal ME if enzymes were not supplemented. The recommendation is still valid if the enzymes are supplemented in the diet. The nutrient density for the grower diet (age $>4$ to 20 weeks) recommended by the SNI was 56g CP/Mcal ME (BSN, 2013b). This experiment showed the best nutrient density for grower and finisher diet was $66.1 \mathrm{~g} \mathrm{CP} / \mathrm{Mcal} \mathrm{ME}$ if enzymes were not supplemented. However, the best nutrient density for the grower (age 5 to 8 weeks) and finisher (age 9 to 12 weeks) period was 66.1 and $59.3 \mathrm{~g}$ $\mathrm{CP} / \mathrm{Mcal} \mathrm{ME}$, respectively, when enzymes were supplemented in the diet. Different growth rates due to the breeding selection may be the reason for the difference in nutrient density requirement of KUB chickens with the SNI recommendations. Therefore, the SNI recommendation needs to be adjusted if applied to formulate feed for KUB chickens.

\section{CONCLUSION}

Feeding KUB chickens with different nutrient densities and enzyme supplementations influenced feed efficiency utilization. Different nutrient densities should be applied when enzymes are supplemented in the diet.
The best performance of KUB chickens was achieved when fed with a high-density diet for the starter period, followed by a medium-density diet for the grower and finisher period without enzyme supplementation. However, the best performance of KUB chickens was achieved when fed with a medium density diet for starter and grower and followed by a low (L) density diet for the finisher period with enzyme supplementation.

\section{CONFLICT OF INTEREST}

The authors declared no conflict of interest with financial support and materials used in conducting the experiment and writing this paper.

\section{ACKNOWLEDGEMENT}

This research was funded by National Research Priority Program (PRN) 2020, under the collaboration between the Indonesian Ministry of Research and Technology and Agency for Agriculture Research and Development. The authors appreciate the helps of Drs. Helmy Hamid and Ms. Nila Miraya for producing and analyzing enzymes, Mr. Uci for caring for the animals, and drh. Tri Wardhani for caring the animal health during the trial.

\section{REFERENCES}

Abdallh, M. E., E. U. Ahiwe, S. Musigwa, E. P. Chang'a, M. Al-Qahtani, D. J. Cadogan, \& P. A. Iji. 2020. Energy and protein utilisation by broiler chickens fed diets containing cottonseed meal and supplemented with a composite enzyme product. Br. Poult. Sci. 61: 424-432. https://doi.org/10 $.1080 / 00071668.2020 .1736266$

Abudabos, A. M. 2012. Effect of enzyme supplementation to normal and low density broiler diets based on corn-soybean meal. Asian J. Anim. Vet. Adv. 7:139-148. https://doi. org/10.3923/ajava.2012.139.148

Amerah, A. M., L. F. Romero, A. Awati, \& V. Ravindran. 2017. Effect of exogenous xylanase, amylase, and protease as single or combined activities on nutrient digestibility and growth performance of broilers fed corn/soy diets. Poult. Sci. 96: 807-816. https://doi.org/10.3382/ps/pew297

Balasubramanian, B., S. L. Ingale, J. Hong Park, P. C. Rathi, S. Shanmugam, \& I. H. Kim. 2018. Inclusion of dietary $\beta$ mannanase improves performance and ileal digestibility and reduces ileal digesta viscosity of broilers fed corn-soybean meal based diet. Poult. Sci. 97:3097-3101. https://doi. org/10.3382/ps/pey157

BSN [Badan standard Nasional]. 2013a. SNI 7783.1-2013. Pakan ayam buras - Bagian 1:Starter. BSN, Jakarta

BSN [Badan standard Nasional]. 2013b. SNI 7783.2-2013. Pakan ayam buras - Bagian 2: Grower. BSN, Jakarta

BSN [Badan standard Nasional]. 2016a. SNI-8290.1-2016Pakan-ayam-raspetelur-Bagian-1-sebelum-masa-awallayer-prestarter. BSN, Jakarta

BSN [Badan standard Nasional]. 2016b. SNI-8290.2-2016Pakan-ayam-ras-petelur-Bagain-2-Masa-awal-Layerstarter. BSN, Jakarta

BSN [Badan standard Nasional]. 2016c. SNI-8290.3-2016Pakan-ayam-ras-petelur-Bagian-3-Dara-Layer-grower. BSN, Jakarta

Classen, H. L. 2017. Diet energy and feed intake in chickens. Anim. Feed Sci. Tech. 233:13-21. https://doi.org/10.1016/j. anifeedsci.2016.03.004 
El-Kelawy, M. I., A. S. El-Shafey, \& R. M. Ali. 2017. Impact of dietary supplementation with multi-enzyme and/or probiotics on productive performance and nutrients digestibility of broiler chickens. Egyp. J. Nut. Feed 20: 535-543. https://doi.org/10.21608/ejnf.2017.75331

Hajati, H. 2010. Effects of enzyme supplementation on performance, carcass characteristics, carcass composition and some blood parameters of broiler chicken. Am. J. Anim. Vet Sci. 5: 221-227. https://doi.org/10.3844/ajavsp.2010.221.227

Hidayat, C., S. Iskandar. T. Sartika, \& T. Wardhani. 2017. Growth response of improved native breeds of chicken to diets differed in energy and protein content. J. Ilmu Ternak Vet. 21: 174-. https://doi.org/10.14334/jitv.v21i3.1397

Hussein, E. O. S., G. M. Suliman, A. N. Alowaimer, S. H. Ahmed, M. E. Abd El-Hack, A. E. Taha, \& A. A. Swelum. 2020. Growth, carcass characteristics, and meat quality of broilers fed a low-energy diet supplemented with a multienzyme preparation. Poult. Sci. 99: 1988-1994. https://doi. org/10.1016/j.psj.2019.09.007

Irawan, H., S. Tantalo, \& K. Nova. 2018. Performa ayam kub unsex periode finisher (9--12 minggu) pada pemberian ransum dengan kadar protein berbeda. Performance of chicken kub unsex finisher period (9-12 weeks) on rations supply with different level protein. J. Riset dan Inovasi Peternakan 2:27-33

Jabbar, A., M. Tahir, R. U. Khan, \& N. Ahmad. 2021. Interactive effect of exogenous protease enzyme and dietary crude protein levels on growth and digestibility indices in broiler chickens during the starter phase. Trop. Anim. Health Prod. 53:23. https://doi.org/10.1007/s11250-020-02466-5

Kalmendal, R. \& R. Tauson. 2012. Effects of a xylanase and protease, individually or in combination, and an ionophore coccidiostat on performance, nutrient utilization, and intestinal morphology in broiler chickens fed a wheat-soybean meal-based diet. Poult. Sci. 91 :1387-1393. https://doi. org/10.3382/ps.2011-02064

Kim, S. J., K. W. Lee, C. W. Kang, \& B. K. An. 2016. Growth performance, relative meat and organ weights, cecal microflora, and blood characteristics in broiler chickens fed diets containing different nutrient density with or without essential oils. Anim Biosci. 29: 549-554. https://doi. org/10.5713/ajas.15.0426

Lamot, D. M., D. Sapkota, P. J. A. Wijtten, I. van den Anker, M. J. W. Heetkamp, B. Kemp, \& H. van den Brand, 2019. Diet density during the first week of life: Effects on growth performance, digestive organ weight, and nutrient digestion of broiler chickens. Poult. Sci. 98: 789-795. https://doi. org/10.3382/ps/pey002

Mayora, I. W., S. Tantalo, K. Nova, \& R. Sutrisna. 2018. Performa ayam KUB (Kampung Unggul Balitnak) periode starter pada pemberian ransum dengan protein kasar yang berbeda. J. Riset dan Inovasi Peternakan. 2: 2598-3067.
Puteri, N. I., Gushairiyanto, \& Depison. 2020. Growth patterns, body weight, and morphometric of KUB chicken, Sentul chicken and Arab chicken. Buletin Peternakan 44: 67-72. https://doi.org/10.21059/buletinpeternak.v44i3.57016

Sari, M. L., S. Tantolo, \& K. Nova. 2017. Performa ayam KUB (kampung unggul balitnak) periode grower pada pemberian ransum dengan kadar protein kasar yang berbeda. J. Riset dan Inovasi Peternakan. 1: 36-41.

Saragih, H. T. S., F. Viniwidihastuti, R. P. Lembayu, A. R. Kinanthi, H. Kurnianto, \& I. Lesmana. 2019. Phenotypic characteristics of exotic-broiler, kampung, male exoticlayer, KUB-1 and pelung chickens. JITV. 24: 9-14. https:// doi.org/10.14334/jitv.v24i1.1889

Shu-Biao, W., R. A. Swick, J. Noblet, N. Rodgers, D. Cadogan, \& M. Choct. 2019. Net energy prediction and energy efficiency of feed for broiler chickens. Poult. Sci. 98: 1222-1234. https://doi.org/10.3382/ps/pey442

Sinurat, A. P., T. Purwadaria, \& T. Pasaribu. 2013. Improving nutrient values of palm kernel cake (PKC) by reducing shell contamination and enzymes supplementation. JITV. 18: 34-41. https://doi.org/10.14334/jitv.v18i1.254

Sinurat, A. P., T. Purwadaria, P. P. Ketaren, \& T. Pasaribu. 2014. Substitutions of soybean meal with enriched palm kernel meal in laying hens diet. JITV. 19: 184-192. https:// doi.org/10.14334/jitv.v19i3.1081

Sinurat, A. P., T. Purwadaria, \& M. Purba. 2015. Effect of enzyme supplementation on nutritive values of fermented palm kernel cake used to substitute soybean meal in broiler diet. JITV. 20: 184-192. https://doi.org/10.14334/jitv. v20i3.1185

Sun, Y., S. Tang, Y. Chen, D. L. Li, Y. L. Bi, D. K. Hua, C. Chen, Q. Y. Luo, L. Yang, \& J. L. Chen. 2017. Effects of light regimen and nutrient density on growth performance, carcass traits, meat quality, and health of slowgrowing broiler chickens. Livest. Sci. 198: 201-208.

Wang, X. Q., W. Jiang, H. Z. Tan, D. X. Zhang, H. J. Zhang, S. Wei, \& H. C. Yan. 2013. Effects of breed and dietary nutrient density on the growth performance, blood metabolite, and genes expression of target of rapamycin (TOR) signalling pathway of female broiler chickens. J. Anim. Physiol. Anim. Nut. 97: 797-806. https://doi. org/10.1111/j.1439-0396.2012.01320.x

Zaefarian, F., M. R., Abdollahi, \& V. Ravindran. 2015. Starch digestion in broiler chickens fed cereal diets. Anim. Feed Sci. Tech. 209:16-29. https://doi.org/10.1016/j. anifeedsci.2015.07.020

Zhai, W., E. D. Peebles, C. D. Zumwalt, L. Mejia, \& A. Corzo. 2013. Effects of dietary amino acid density regimens on growth performance and meat yield of Cobb $\times$ Cobb 700 broilers. J. Appl. Poult. Res. 22: 447-460. https://doi. org/10.3382/japr.2012-00658 